\title{
Histopathological spectrum of lesions in women with postmenopausal bleeding
}

\author{
Vidya Vasudevi,", Geetha $S^{2}$, Rejani K. ${ }^{3}$, Bharthi. $M^{4}$ \\ ${ }^{\mathbf{1}}$ Assistant Professor, ${ }^{2}$ Post Graduate, ${ }^{3} \mathrm{HOD}$, Dept. of Pathology, Mysore Medical College \& Research Institute Karnataka, India
}

*Corresponding Author:

Email: vidyammcri@gmail.com

Received: $23^{\text {rd }}$ September, 2017

Accepted: $15^{\text {th }}$ February, 2018

\begin{abstract}
Introduction: Postmenopausal bleeding is regarded as an omnious and serious alarm of genital pathology. It is a symptom having various etiology and has a strong association with malignancy, which demands its thorough evaluation.

Aims and Objectives: The present study was carried out to know the causes of postmenopausal bleeding based on histopathology and the percentage of various benign premalignant \& malignant lesions in postmenopausal bleeding. The association with age was also studied.

Methodology: This study included 139 specimens received in in Department of Pathology MMC \& RI Mysore, with history of postmenopausal bleeding, from January 2013 to December 2014.

Results: Mean age of the patients in the study was 57 years. Cervical biopsy was most common biopsy received (43.8\%). Benign cases were $51.6 \%$, malignant cases $36.07 \%$ and premalignant lesions were $9.27 \%$. Among the benign lesions atrophic endometrium was most common (11.2\%). Cervical cancer was most common (33\%) among malignancy.

Conclusion: Any patient presenting with history of postmenopausal bleeding should be investigated thoroughly to determine the cause of bleeding. Cervical lesions are still the most common cause postmenopausal bleeding so screening programme should be effectively implemented.
\end{abstract}

Keywords: Postmenopausal bleeding, Histopathology.

\section{Introduction}

Menopause is taken from the Greek word "Meno" (month) \& "pause" means stop. Menopause occurs physiologically in women who are about the age of $50 .{ }^{1}$ Most women all over the world attain menopause at 45$55 \mathrm{yrs}$ with the average age $51 \mathrm{yrs}^{2}$ Vaginal bleeding which occurs after one year of amenorrhea in a woman of the age in which menopause can be expected is defined as postmenopausal bleeding. ${ }^{3}$ In gynecological practice PMB represents for $5 \%$ of cases. ${ }^{4}$ Cancer is an important cause of this abnormal bleeding, with the dictum is that postmenopausal bleeding indicates malignancy until proven otherwise. ${ }^{5-17}$ The dictum is that postmenopausal bleeding always indicates malignancy until proven otherwise. ${ }^{11}$ In postmenopausal women with vaginal bleeding the probability of endometrial carcinoma is approximately $10 \% .{ }^{18}$ Malignant tumors account for $7-49 \%$ of cases of PMB and this depends on racial, genetic, ethnic differences in incidence of malignancy in diverse population as well as to different criteria adopted by different studies. The present era life expectancy of women have increased \& most will experience the postmenopausal phase. The chances of malignancy increases with increase in age of onset of PMB. Most studies on PMB are based on endometrial biopsies. Since few of studies describing the histological spectrum of lesions in entire genital tract the present study was undertaken to examine the lesions in genital tract in cases of PMB.

\section{Aims and Objectives}

The present study was carried out to know the causes of postmenopausal bleeding based on histopathology and the percentage of various benign premalignant \&malignant lesions in postmenopausal bleeding. The association with age was also studied.

\section{Materials and Methods}

The present study was conducted for a period of 2 years from January 2013 to December 2014 at Department of Pathology, MMC\&RI. Material for study was collected from endometrial, cervical, vaginal, vulval biopsies and hysterectomy specimens which were sent for histopathological examination to Department of Pathology from clinically diagnosed cases of postmenopausal bleeding. The History noted were spotting per vagina, brownish discharge, scanty flow and moderate to profuse bleeding. Premature menopause whether surgical or natural, with age $<40 \mathrm{yrs}$ and patient on hormonal replacement therapy/on anticoagulant/having bleeding disorders were excluded from the study. After the collection of detailed data, the specimens were examined grossly. Specimens were fixed in $10 \%$ buffered formalin. Sections were processed and stained with $\mathrm{H}$ \& E. Slides were examined under microscope and observations were done. The results were compiled, analysed using proportion and compared with other studies. 


\section{Results}

The study comprised of 139 cases which met the inclusion criteria were taken for this study. Age of the patients with post menopausal bleed (Table 1) ranged between 41-80 years with the mean age of 57yrs. The maximum number of cases $36(25.8 \%)$ were between the age group of $46-50$ years. The most common site biopsy received were from cervix, 61(43.8\%). (Table 2)

Postmenopausal bleeding was due to benign causes in 78 cases $(51.6 \%)$. (Table 3) Atrophic endometrium was the commonest benign cause comprising total 19 cases (11.7\%). Proliferative endometrium 15 cases (9.2\%), endometrial hyperplasia without atypia 11 cases (6.7\%), cervicitis 6 cases $(3.7 \%)$, cervical polyp 6 cases (3.7\%), endometrial polyp 5 cases (3\%), adenomyosis 3 cases $(1.55 \%)$, leiomyoma 3 cases $(1.55 \%)$ and one case of endometritis $(0.6 \%) \&$ one case of prolapse $(0.6 \%)$. Inadequate samples were 11 cases $(6.7 \%)$.

Most of the malignant tumors were from the cervix 55 cases (33\%) (Table 3) followed by uterine malignancy 15 cases (9.2\%), Carcinoma vulva 3 cases $(1.85 \%)$, Carcinoma vagina 2 cases $(1.23 \%)$. The ratio of malignant tumor in cervix to those in uterus was 2.9:1 (Table 4). Among the malignant lesions squamous cell carcinoma was the most common 46 (28.35\%). The number of benign lesions added up to more than $100 \%$ as these lesions overlapped that is one specimen had more than one lesion.

Table 1: Distribution of study subjects according to age groups

\begin{tabular}{|l|c|c|}
\hline $\begin{array}{l}\text { AGE } \\
\text { (years) }\end{array}$ & $\begin{array}{c}\text { No of study } \\
\text { subjects }\end{array}$ & Percentage \\
\hline $41-45$ & 11 & 7.9 \\
\hline $46-50$ & 36 & 25.8 \\
\hline $51-55$ & 28 & 20.1 \\
\hline $56-60$ & 26 & 18.7 \\
\hline $61-65$ & 18 & 12.9 \\
\hline $66-70$ & 13 & 9.3 \\
\hline$>70$ & 6 & 4.3 \\
\hline$>80$ & 1 & 0.7 \\
\hline Total & 139 & 100 \\
\hline
\end{tabular}

Table 2: Type of specimens received

\begin{tabular}{|l|c|c|}
\hline Type of specimen & Numbers & Percentage \\
\hline Biopsy vulva and vagina & 4 & 2.83 \\
\hline Biopsy cervix & 61 & 43.8 \\
\hline Biopsy cervix and endometrium & 13 & 9.3 \\
\hline Endometrial curettage & 42 & 30.2 \\
\hline Hysterectomy & 7 & 5.03 \\
\hline Hysterectomy with adnexa & 11 & 7.9 \\
\hline Hysterectomy with adnexa, omentum and lymph nodes & 1 & 0.7 \\
\hline Total & 139 & 100 \\
\hline
\end{tabular}

Table 3: Distribution and percentage of various lesions

\begin{tabular}{|l|c|c|c|}
\hline S. No & Histopathology diagnosis & Number & Percentage \\
\hline 1 & Indequate & 11 & 6.7 \\
\hline 2 & Cervicitis & 6 & 3.7 \\
\hline 3 & Cervical polyp & 6 & 3.7 \\
\hline 4 & Atrophic endometrium & 19 & 11.7 \\
\hline 5 & proliferative endometrium & 15 & 9.2 \\
\hline 6 & Endometrial hyperplasia without atypia & 11 & 6.7 \\
\hline 7 & Endometrial hyperplasia with atypia & 3 & 1.85 \\
\hline 8 & Endometrial polyp & 5 & 3 \\
\hline 9 & Endometritis & 1 & 0.6 \\
\hline 10 & Adenomyosis & 3 & 1.85 \\
\hline 11 & Leiomyoma & 5 & 3 \\
\hline 12 & Prolapse & 1 & 0.6 \\
\hline 13 & Carcinoma cervix(total) & 55 & 3 \\
\cline { 2 - 4 } & CIN & 11 & 6.7 \\
\cline { 2 - 4 } & SCC & 42 & 25.9 \\
\cline { 2 - 4 } & Undifferentiated & 2 & 1.23 \\
\hline \multirow{3}{*}{14} & Malignant Uterus (Total) & 15 & 9.5 \\
\cline { 2 - 4 } & Adenocarcinoma & 2 & 6.2 \\
\cline { 2 - 4 } & Adenosquamous carcinoma & 10 & 1.2 \\
\hline
\end{tabular}




\begin{tabular}{|l|c|c|c|}
\hline & Papillary Serous Carcinoma & 2 & 1.2 \\
\cline { 2 - 4 } & MMMT & 1 & 0.6 \\
\hline 15 & Carcinoma Vulva (SCC) & 3 & 1.85 \\
\hline 16 & $\begin{array}{c}\text { Carcinoma Vagina } \\
\text { (SCC and Adenocarcinoma) }\end{array}$ & 2 & 1.23 \\
\hline \multicolumn{2}{|c|}{ Total } & 162 & 100 \\
\hline
\end{tabular}

Table 4: Distribution of lesions

\begin{tabular}{|l|c|c|c|}
\hline S. No & Histopathology & Number of cases & Percentage \\
\hline 1 & Benign & 78 & 51.6 \\
\hline 2 & Malignant & 59 & 39.07 \\
\hline 3 & Premalignant & 14 & 9.27 \\
\hline & Total & 151 & 100 \\
\hline
\end{tabular}

\section{Discussion}

PMB means bleeding from genital tract occurring in postmenopausal women after 12 months of amenorrhea in a women of postmenopausal age. ${ }^{19} \mathrm{PMB}$ is frequent and accounts for 5\% of gynecological presentations. ${ }^{4}$ In PMB the incidence of malignancy is very high, so it requires immediate investigations for early diagnosis, follow up and prompt treatment. In present era life expectancy has increased and women tend to live longer and many will experience the postmenopausal phase. PMB is a very alarming sign that may be associated with cervical or uterine malignancy.

The investigations and assessment is moving away from operation theatre, ward environment into outpatient department. However the primary assessment in all cases of PMB should be trans vaginal ultrasound scanning(TVS) as the thickening of endometrium may indicate significant pathology. ${ }^{20}$ The present trend in investigating only lesions with PMB when endometrial thickness is $>4 \mathrm{~mm}$ as measured by ultrasound. ${ }^{21}$ However the authors have recommended systematic collection of biopsies from symptomatic patients ${ }^{22}$ because there have been reports of cancer in patients presenting with ultrasound measured endometrial thickness $<5 \mathrm{~mm}{ }^{23}$

In the present study it was noted that maximum number of cases that is $(25.8 \%)$ were in the age group of 46-50 years while minimum number of cases(7.9\%) were in 41-45 yrs. In the present study age range was from 41-80 yrs while the study done by Way sf et al, Sousa R et al, Bharani B et al and Sheikh M et al was 38-94, 43-82,52-65, 42-84 yrs respectively. ${ }^{24-27}$

Mean age of the present study was 57yrs whereas in other studies it was 47.43 to $56.5 y$ yrs. ${ }^{28}$ It was also noted that as the age of subjects increases the incidence of PMB decreases which shows an inverse relationship between age and age of PMB. In study done by Gredmark $\mathrm{T}$ et al, the number of cases of PMB decreased with increasing age. ${ }^{16}$

In this present study 139 samples were received which were biopsy specimens from cervix, endometrium, vulva, vagina and hysterectomy specimens. Benign conditions were $51.6 \%$, malignant $39.07 \%$ and premalignant $9.27 \%$. (Table 5) Benign conditions included cervicitis, cervical polyp, atrophic endometrium, proliferative endometrium without atypia, endometrial polyp, endometritis, adenomyosis, leiomyoma and prolapse. It was noted that atrophic endometrium (Fig. 1) was the most common histological lesion in benign conditions that is 19 cases (11.7\%), followed by proliferative endometrium 15 cases $(9.2 \%)$. (Table 6) But atrophy was found to be $49.9 \%$ by Gredmark et al ${ }^{16} 52 \%$ by Lee $\mathrm{WH}$ et al, ${ }^{12}$ $16.3 \%$ by Naik et al, ${ }^{11} 32 \%$ by Cheema et al. ${ }^{2}$ The probable explanation for unexplained bleeding from atrophic endometrium are fluctuation of serum levels of estrogen, nonspecific chronic endometritis, sclerotic degeneration of myometrial arterioles, associated diabetes mellitus \& hypertension, uterus prolapse causing passive congestion\& bleeding, rupture of endometrial cysts. ${ }^{29}$

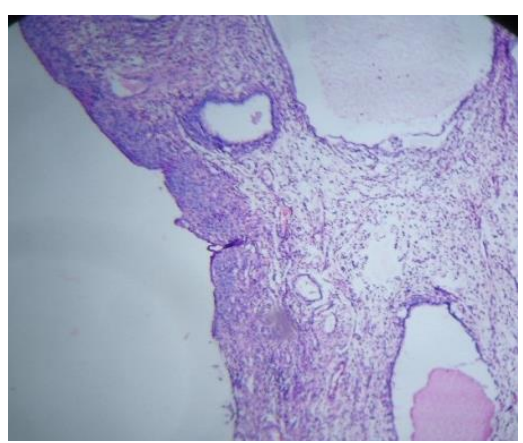

Fig. 1: Atropic endometrium(H\&E x 10x)

In the present study it was noted that proliferative endometrium was in 15 cases $(9.2 \%)$ which is comparable to study of Naik et al ${ }^{11}$ who found it to be $8.6 \%$ and Cheema et al $8 \% .^{2}$ Choo YC et al found out that stimulation of postmenopausal endometrium can occur because of conversion of adrenal androsteinedione by peripheral fat to estrogen which leads to proliferative endometrium and also fluctuation of low level of estrogen results in bleeding from proliferative endometrium. ${ }^{30}$ 
Table 5: Ratio of cervical and uterine cancer in different studies

\begin{tabular}{|l|c|}
\hline Study & $\begin{array}{c}\text { Ratio of cervical and } \\
\text { uterine carcinoma }\end{array}$ \\
\hline Lee et al & $1.2: 1$ \\
\hline Tyagi et al & $2.6: 1$ \\
\hline Present study 2015 & $2.9: 1$ \\
\hline
\end{tabular}

Table 6: Distribution of various lesions in different studies

\begin{tabular}{|l|c|c|c|c|c|c|}
\hline & Lee 1995 & $\begin{array}{c}\text { Gredmark } \\
\mathbf{1 9 9 5}\end{array}$ & Naik 2005 & $\begin{array}{c}\text { Cheema } \\
\mathbf{2 0 0 8}\end{array}$ & $\begin{array}{c}\text { Tyagi } \\
\mathbf{2 0 1 0}\end{array}$ & $\begin{array}{c}\text { Present } \\
\text { Study }\end{array}$ \\
\hline Ca vagina and vulva & 0.6 & & & & 4.3 & 1.23 \\
\hline Ca cervix & 12.9 & & 39 & 14 & 34.5 & 33 \\
\hline Ca uterine & 11 & 8 & 9.6 & 10 & 13 & 9.2 \\
\hline Ca ovary & 1.2 & & 0.96 & 6 & 5.5 & \\
\hline Cervicitis & 12.9 & & 2.8 & 68 & 2.1 & 3.7 \\
\hline Polyp & 6.7 & 9 & & 16 & 16 & 3 \\
\hline Proliferative endometrium & & 4 & 8.6 & 8 & 1.5 & 9.2 \\
\hline Secretary endometrium & & 1 & & 14 & 1.2 & \\
\hline Atrophic endometrium & & 50 & 16.3 & 32 & 2.4 & 11.7 \\
\hline Endometrial hyperplasia & 3.1 & 10 & 13.4 & 2 & 4.9 & 8.5 \\
\hline Leiomyoma & 4.3 & & & & 1.8 & 1.85 \\
\hline Endometritis & 1.2 & & & & & 0.6 \\
\hline Inadequate & 24.5 & 14 & & 4 & 5.2 & 6.7 \\
\hline
\end{tabular}

In endometrial polyp bleeding can be as a result of injury to thin walled vein below surface epithelium or thrombosis of the vessels. The bleeding in leiomyoma can occur due to congestion or atrophy\& thinning of overlying endometrium and myometrium results in ulceration and bleeding. ${ }^{31}$

PMB due to malignant and premalignant cases in present study was $48.2 \%$ (Table 7) which is comparable with Naik et al ${ }^{11} 49 \%$ and Tyagi et $\mathrm{al}^{31} 58.5 \%$. Other studies were Gredmark et al ${ }^{16} 15 \%$, Lee et al ${ }^{12} 25.8 \%$ and Cheema et ${ }^{2}$ al $30 \%$. The ratio of cervical to uterine cancer was 2.9:1 similar to Tyagi et $\mathrm{al}^{31}$ 2.6:1 and Lee et $\mathrm{al}^{12}$ it was 1.2:1. Cervical cancer was responsible for $33 \%$ of PMB, squamous cell carcinoma was the most common cancer (25.9\%). (Fig. 2)

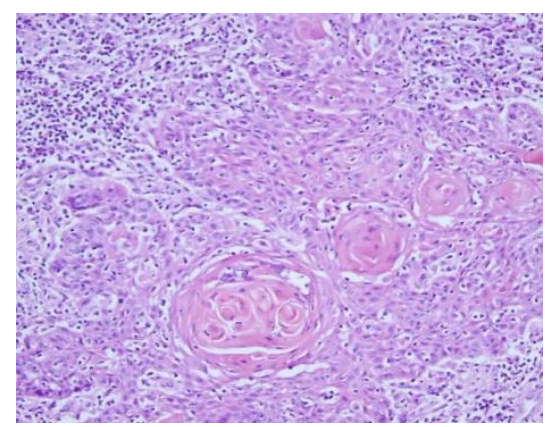

Fig. 2: Well differentiated Squamous cell carcinoma of cervix (H\&E x40x)
Table 7: Incidence of malignant tumors in case of postmenopausal bleeding

\begin{tabular}{|l|c|}
\hline Study & Malignant lesions \\
\hline Gredmark et al & 15 \\
\hline Lee et al & 25.8 \\
\hline Naik et al & 49.1 \\
\hline Cheema et al & 30.0 \\
\hline Tyagi et al & 58.5 \\
\hline Present Study & 48.2 \\
\hline
\end{tabular}

Hence cervical cancer is almost thrice as common as endometrial cancer in our study of women with postmenopausal bleeding. These results support the fact that the diagnostic focus in our country with history of PMB should be towards excluding cervical pathology.

In this study endometrial adenocarcinoma is the most common $(9.2 \%)$ cause of PMB after cervical carcinoma which was similar to Naik et $\mathrm{al}^{11} 9.6 \%$. Other studies were Gredmark et $\mathrm{al}^{16} 8 \%$, Cheema et $\mathrm{al}^{2}$ $10 \%$, Lee et al ${ }^{12} 11 \%$, Tyagi et al ${ }^{31} 13 \%$. Histologically 12 cases $(7.4 \%)$ were there of adenocarcinoma in which $9(5.4 \%)$ were endometrioid adenocarcinoma, 2 cases $(1.2 \%)$ were papillary serous adenocarcinoma and $1(0.6 \%)$ case was endometriod carcinoma with mucinous differentiation. Also reported was one case of MMMT (0.6\%). (Fig. 3) 


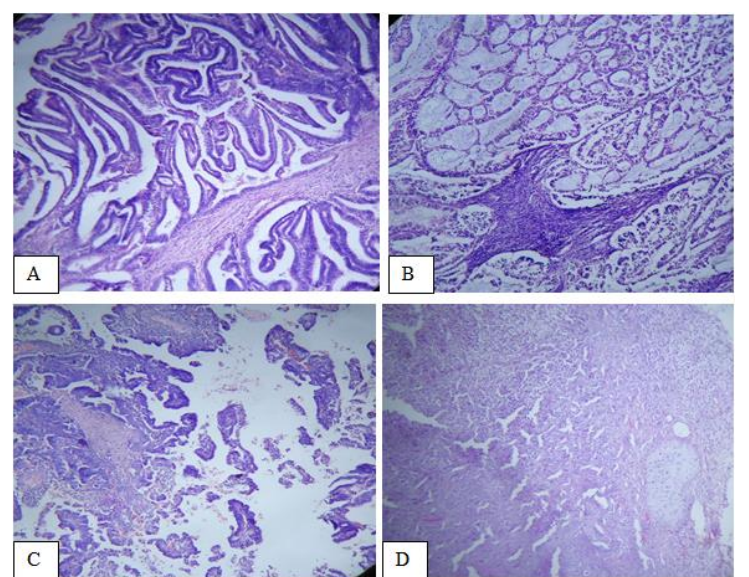

Fig. 3: Endometrial carcinoma.

A: Endometrioid carcinoma.

B: Endometrioid carcinoma with mucinous differentiation.

C: Papillaryserous carcinoma.

D: Malignant mixed mullerian tumor $(\mathrm{H} \& E x$ 10x $)$

Simple endometrial hyperplasia was observed in 11 cases $(6.7 \%), 3$ cases were endometrial hyperplasia with atypia $(1.85 \%)$. Hyperplasia is significant that it carries the risk of development of endometrial cancer more so with hyperplasia with atypia. Other studies were $3-13 \% .^{2,11,12,16}$

\section{Conclusion}

PMB is a symptom which should not be taken lightly. Accurate diagnosis is usually made by histopathological examination. In our study, a wide spectrum of both neoplastic and non- neoplastic conditions of female genital tract has displayed as a cause of PMB with predominance of benign causes $(51.6 \%)$. The main aim of evaluation of PMB is to exclude premalignant and malignant lesions. Cervical cancer is still the most common cause of PMB, which point out that the effective implementation of screening program is utmost important. More awareness among people, especially elderly women should be made about the importance of pap screening.

PMB indicates malignancy until proved otherwise and it demands thorough evaluation of patients with histopathological confirmation. An accurate diagnosis is immensely important as it will be helpful for the management of patient by implementing a proper treatment plan.

\section{References}

1. Dawood NS, Peter K, Ibrar F, Dawood A. PMB causes and risk of genital tract malignancy. $\mathrm{J}$ Ayub Medical coll. Abbottabad 2010;22:117-20.

2. Cheema SZ, Saeed R, Ikram M, Saeed M. Postmenopausal bleeding. Professional Med J 2008;15:32834.
3. Miyazawa K. Clinical significance of an enlarged uterus in patients with postmenopausal bleeding. Obstet Gynecol 1983;61:148-52.

4. Carlos RC, Bree RL, Abrahamse PH, Fendrick AM. Cost effectiveness of saline assisted hysterosonography and office hysteroscopy in the evaluation of PMB. Acad Radiol 2001;8:835-44.

5. Escoffery CT, Blake GO, Sargeant LA. Histopathological findings in women with postmenopausal bleeding in Jamaica. West Ind Med J 2002;51:232-5.

6. Sarfraz T, Tariq H. Endometrial biopsy findings in postmenopausal bleeding. Pak J Pathol 2007;18:4-6.

7. Giusa-Chiferi MG, Goncalves WJ, Baracat EC, Cavalcanti de Albuquerque Neto L, Bortoletto CCR, Rodrigues de Lima G. Transvaginal ultrasound, uterine biopsy and hysteroscopy for postmenopausal bleeding. Int J Gynecol Obstet 1996;55:39-44.

8. Ghazi A, Jabbar S, Siddiqui N. Frequency of endometrial carcinoma in patients with postmenopausal bleeding. Pak J surg 2005;21:41-4.

9. Garuti G, Sambruni I, Cellani F, Garzia D, Alleva P, Luerti M. Hysteroscopy and transvaginal ultrasonography in postmenopausal women with uterine bleeding. Int $\mathbf{J}$ Gynecol Obstet 1999;65:25-33.

10. Dwnes E, Al-Azzawi F. The predictive value of outpatient hysteroscopy in a menopause clinic. $\mathrm{Br} \mathbf{J}$ ObstetGynecol 1993;100:1148-9.

11. Naik VS, Rege JD, Jashnani KD. Pathology of genital tract in postmenopausal bleeding. Bombay Hospital Journal 2005;47:14-7.

12. Lee WH, Tan KH, Lee YW. The aetiology of postmenopausal bleeding- a study of 163 consecutive cases in Singapore. Singapore Med J 1995;36:164-8.

13. Lidor A, Ismajovich B, Confino E, David MP. Histopathological findings in 226 women with postmenopausal uterine bleeding. Acta Obstet Gynecol Scand 1986;65:41-3.

14. Asaf KH, Samina, Hamid. Causes of Postmenopausal Bleeding. Pak J Obstet Gynaecol 1997;10:22-6.

15. Asim SS, Akhtar AZ. Frequency of malignancy in women presenting with postmenopausal bleeding. Ann Abbasi Shaheed Hospital Karachi Med Dent Coll 2004;9:506-9.

16. Gredmark T, Kvint S, Havel G, Mattsson LA. Histopathological findings in women with postmenopausal bleeding. Br J Obstet Gynaecol 1995;102:133-6.

17. Merril JA. Management of postmenopausal bleeding. Clin Obstet Gynecol 1981;24:285-99.

18. Smith- Bindman R, Kerlikowske K, Feldstein VA et al. Endovaginal ultrasound to exclude endometrial cancer \& other abnormalities. The Journal of American Medical Association. 1998;280:1510-17.

19. PMB (Internet).Patent.co.UK. Accsessed June 162014. Available from www.patent.co.uk

20. Wolman I, Amster R, Hartoov J et al. Reproducibility of transvaginal ultrasonographic measurements of endometrial thickness in patients with postmenopausal bleeding. Gynecol Obstet Invest 1998;46:191-94.

21. Biriniyi L, Darago P, Torok P et al. Predictive value of hysteroscopic examination in intrauterine abnormalities. Eur J. Obstet Gynecol. Reprod Biol 2004;115(1):75-79.

22. Tabor A, Watt HC, Wald NJ. Endometrial thickness as a test for endometrial cancer in women with postmenopausal bleeding. Obstet Gynecol 2002;99(4):663-70.

23. Litta P, Merlin F, Saccordic C et al. Role of hysteroscopy with endometrial biopsy to rule out endometrial cancer in 
postmenopausal women with abnormal uterine bleeding. Marturitas 2005;50(2):117-23.

24. Wong SF, Luk KL, Wong AY, Tang LC. Finding in women with postmenopausal bleeding investigated with hysteroscopy. J Obstet Gynecol 2001;21:392-95.

25. Sousa R, Silvestre M, Almedia e Sousak, Falco F, Dias I, Silva T, De Oliveria C, Oliveria HM. Transvaginal ultrasonography and hysteroscopy in postmenopausal bleeding a prospective study. Acta Obstet Gynecol Scand 2001;80:856-62.

26. Bharani B, Phatak SR. Feasibility and yield of endometrial biopsy using suction curette device for evaluation of abnormal pre and postmenopausal bleeding. J Obstet Gynecol India. 2008;58:322-6.

27. Sheikh M, Sawhney, Khurana A, Al Yatama M. Alteration of sonographic texture of the endometrium in PMB a guide to further management. Acta Obstet Gynecol Scand. 2009;79:1006-50.

28. Yousuf S, Shaheen M and Rana T. Frequency of endometrial carcinoma in patients with postmenopausal bleeding. Annals 2010;16:290-94.

29. Dina GEE, Halah MN. Unexplained postmenopausal uterine bleeding from atrophic endometrium: Histopathological and hormonal studies. Middle East Fertility Society Journal 2015;20:262-70.

30. Choo YC, Mak KC, Hsu C, Wong TS, Ma HK. Postmenopausal uterine bleeding of nonorganic cause. Obstet Gynecol 1985;66:225-28.

31. Tyagi R, Issacs R, Dhar T. Postmenopausal bleeding Histopathological spectrum and association with age \& clear span; case series of 328 cases. Journal of Evolution of Medical and Dental Sciences. 2014;3(26):7210-7221. 